\title{
Settlement Arrangement based on Landslide Risk Analysis in Girirejo, Bantul, Yogyakarta
}

\section{Sri Aminatun, Yunalia Muntafi}

Universitas Islam Indonesia

sri.aminatun@uii.ac.id

\section{Article History}

accepted 31/08/2020

approved 22/08/2020

published $28 / 10 / 2020$

\begin{abstract}
Located on a hilly topography with a steep slope, highlighted the importance of settlement arrangement based on a landslide risk assessment in Girirejo village, Imogiri, Bantul, Yogyakarta. This study aims to map landslides risk, identify houses in the landslide risk zone, and provide recommendations for settlement arrangements. The research begins with observation, interviews, and focus group discussion. Disaster risk mapping and analysis were carried out through weighting method based on Perka BNPB No.2 of 2012 concerning General Guidelines for Disaster Risk Assessment and a formula with parameters of hazard, vulnerability, and capacity. Results showed the medium to a high-level of landslide risk was dominated by northern and eastern parts of Girirejo (21 families in red-zone, 23 families in yellow-zone), while western and southern regions had a low landslide risk level. This research also provided a formulation of settlements concept for medium and high-risk areas by considering landslides risk analysis study.
\end{abstract}

Keywords: Landslide, disaster risk analysis, disaster risk map, settlement arrangement

\begin{abstract}
Abstrak
Terletak pada topografi punggungan perbukitan dengan tingkat kelerengan yang curam melatarbelakangi pentingnya penataan pemukiman berdasarkan kajian risiko bencana longsor di desa Girirejo, Imogiri, Bantul, Yogyakarta. Penelitian ini bertujuan memetakan risiko tanah longsor di desa Girirejo, mengidentifikasi rumah-rumah penduduk yang berada di zona risiko longsor, serta memberikan rekomendasi penataan pemukiman di wilayah tersebut. Penelitian diawali dengan melakukan observasi langsung, wawancara, dan focus group discussion. Pemetaan dan analisis risiko bencana dilakukan dengan metode pembobotan berdasarkan Perka BNPB No.2 tahun 2012 tentang Pedoman Umum Pengkajian Risiko Bencana dan formula risiko bencana dengan parameter ancaman, kerentanan, dan kapasitas. Hasil penelitian menunjukkan tingkat risiko bencana sedang hingga tinggi didominasi wilayah Girirejo bagian utara dan timur ( $21 \mathrm{KK}$ di zona merah, $23 \mathrm{KK}$ di zona kuning), sedangkan wilayah barat dan selatan memiliki tingkat risiko bencana rendah. Penelitian ini juga menghasilkan rumusan konsep permukiman untuk kawasan berisiko menengah dan tinggi dengan mempertimbangkan hasil kajian risiko tanah longsor.
\end{abstract}

Kata kunci: Tanah longsor, analisis risiko bencana, peta risiko bencana, penataan pemukiman

Social, Humanities, and Education Studies (SHEs): Conference Series https://jurnal.uns.ac.id/shes

p-ISSN 2620-9284

e-ISSN 2620-9292 


\section{PENDAHULUAN}

Girirejo merupakan salah satu desa di kecamatan Imogiri yang rawan terjadi tanah longsor, khususnya pada musim hujan. Imogiri merupakan salah satu kecamatan di Kabupaten Bantul, provinsi Daerah Istimewa Yogyakarta yang berada pada wilayah perbukitan. Berdasarkan data Badan Pertanahan Kabupaten Bantul (2009), secara umum, kecamatan Imogiri mempunyai kemiringan lereng yang curam, yaitu 900ha dengan kemiringan 15-25\%, 954ha dengan kemiringan 25-40\%, dan 1.295ha dengan kemiringan lebih dari 40\%. Menurut SNI 13-7124-2005, tanah longsor adalah perpindahan material pembentuk lereng berupa batuan, bahan rombakan, tanah, atau material campuran tersebut yang bergerak ke bawah atau ke luar lereng. Berdasarkan peta prakiraan wilayah terjadinya gerakan tanah pada bulan Desember 2019 yang dikeluarkan oleh Badan Geologi, Kementrian Energi dan Sumber daya Material (2019), desa Girirejo mempunyai potensi terjadi gerakan tanah menengah hingga tinggi seperti yang disajikan pada Gambar 1.

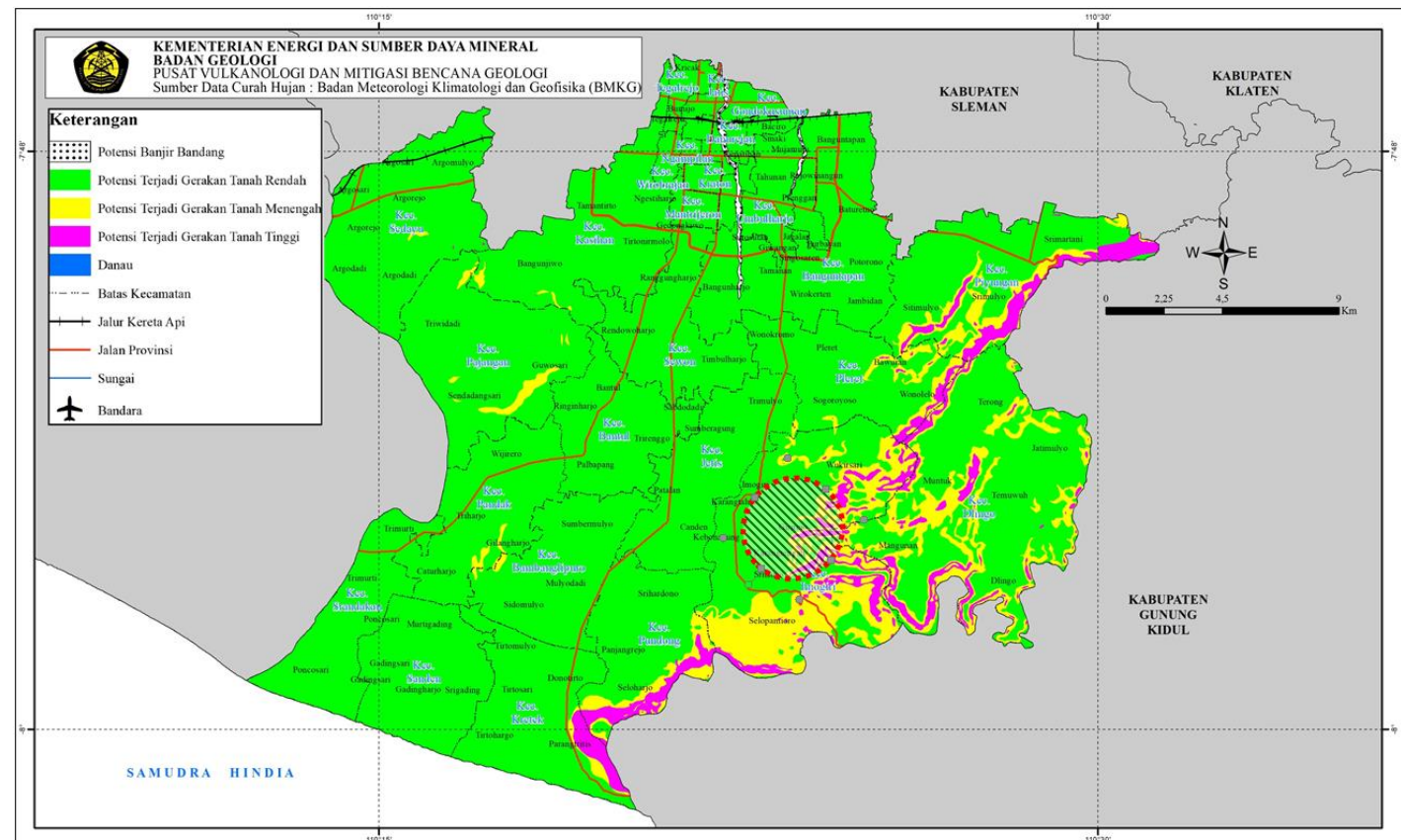

Gambar 1. Peta Prakiraan Wilayah Terjadinya Gerakan Tanah pada Bulan Desember 2019, Kabupaten Bantul dan Kota Yogyakarta

Sumber: Badan Geologi, Kementrian Energi dan Sumber Daya Mineral, 2019

Kajian analisis risiko bencana dengan melakukan pemetaan risiko bencana belum ada standarisasi yang baku dalam penyusunan peta risiko bencananya sehingga setiap lembaga atau institusi memiliki metode yang berbeda. Tahun 2008 Badan Perencanaan Pembangunan Nasional (BAPPENAS) BAPEDA DIY-UNDP mengeluarkan buku berjudul Metode Pemetaan Risiko Bencana Provinsi DIY yang di dalamnya menghasilkan peta risiko bencana provinsi DI. Yogyakarta secara global. Penelitian-penelitian yang telah dilakukan tersebut masih dalam bentuk global, perlu dilakukan penelitian yang lebih detail terkait kajian risiko bencana dan penelitian ini melanjutkan penelitian yang telah di lakukan oleh Bank Dunia bekerjasama dengan pemerintah Kabupaten Bantul untuk analisis risiko bencana tanah longsor.

Pemetaan risiko bencana menjadi sangat penting dalam mendukung upaya penataan penanggulangan bencana yang matang, terarah, dan terpadu (Nugraha, 2013). Beberapa studi terkait pemetaan risiko bencana tanah longsor telah dilakukan, diantaranya oleh Permadi, M.G., dkk. (2018) yang melakukan identifikasi daerah risiko 
bencana longsor di Kota Bogor dengan metode Analytical Hierarchy Process (AHP), Faizana, F., dkk. (2015) yang melakukan pemetaan risiko bencana tanah longsor Kota Semarang dengan mengadopsi metode Vulnerability Capacity Analysis (VCA), dan Khafid, M.A. (2019) yang melakukan analisis zonasi pemukiman risiko bencana longsor berbasis Sistem Informasi Geografis (SIG) di kecamatan Gedangsari, Gunung Kidul. Dalam upaya pengurangan risiko bencana, penataan pemukiman berdasarkan kajian analisis risiko bencana tanah longsor perlu dilakukan sesuai Undang-Undang Penanggulangan Bencana No.24 tahun 2007 dan United Nation-International Strategy for Disaster Reduction (UN-ISDR), (2007), serta implementasi dari hasil konferensi Pengurangan Risiko Bencana yang berupa Kerangka Kerja Sendai untuk Pengurangan Risiko Bencana 2015-2030.

Penelitian bertujuan memetakan daerah risiko bencana tanah longsor, mengidentifikasi jumlah rumah (Kepala Keluarga) yang berada di masing-masing zona risiko bencana (merah, kuning, hijau) dan menentukan strategi penataan pemukiman khususnya pada zona risiko menengah dan tinggi. Penelitian ini merupakan kelanjutan dari penelitian sebelumnya, seperti yang telah dilakukan di desa Terong, Bantul (Aminatun dan Muntafi, 2016) dan desa Sriharjo, Bantul (Aminatun dan Muntafi, 2018). Pemetaan risiko bencana longsor pada penelitian ini memiliki kriteria dan paramater tertentu yang mungkin tidak jauh berbeda dengan lembaga-lembaga dan institusiinstitusi lain tetapi tetap memiliki prinsip parameter kajian peta dasar yang sama.

\section{Metode pengumpulan data}

\section{METODE}

Pengumpulan data dilakukan dengan tahapan berikut:

a. Observasi secara langsung di lapangan,

b. Wawancara dan Focus Group Discussion (FGD) dengan dialog face to face atau diskusi kelompok terarah dengan para key-informan.

c. Dokumentasi dengan mengumpulkan data sekunder berupa dokumen-dokumen yang diperlukan sebagai bahan kajian, termasuk dokumen kajian yang telah disusun sebelumnya

d. Penilaian atau kajian secara langsung di lapangan dengan mengisi form yang telah dipersiapkan dengan parameter-parameter yang telah ditentukan.

\section{Metode analisis data}

Analisis risiko bencana dilakukan dengan metode pembobotan (weighting method) dengan tiga kelas skoring, berdasarkan Perka BNPB No.2 tahun 2012 tentang Pedoman Umum Pengkajian Risiko Bencana dan formula risiko bencana dengan parameter ancaman (hazard), kerentanan (vulnerability), dan kapasitas (capacity). Dari analisis yang telah didapatkan kemudian dilakukan proses pemetaan menggunakan Data Spatial Geographical Information System (ArcGIS) yang didukung oleh peta geologi, peta kemiringan lereng, peta curah hujan dan peta tata guna lahan. Peta yang telah dibuat kemudian disosialisasikan ke basis/desa dengan perwakilan masyarakat untuk memvalidasi hasil peta yang telah dibuat melalui FGD. Hasil sosialisasi awal menjadi evaluasi dalam penyempurnaan pembuatan peta akhir yang kemudian disosialisasikan kembali melalui workshop yang dihadiri oleh Pemda Bantul, perangkat dan perwakilan masyarakat desa kajian, tokoh masyarakat dan stakeholder terkait.

\section{Pembobotan dan Penilaian Parameter Bencana Longsor}

Pembobotan parameter dalam analisis risiko bencana longsor dilakukan berdasarkan Perka BNPB No.2 tahun 2012 tentang Pedoman Umum Pengkajian Risiko Bencana dengan memperhitungkan jumlah nilai maksimal dan jumlah nilai minimal pembobotan. Setelah diketahui harkat dari semua unsur atau indikatornya, 
kemudian masing-masing parameter tersebut dinilai berdasarkan besarnya pengaruh masing-masing unsur. Pembobotan dan hasil penilaian masing-masing parameter bencana longsor di desa Girirejo disajikan pada Tabel 6, Tabel 7, dan Tabel 8.

Tabel 1. Pembobotan dan Penilaian Parameter Ancaman

\begin{tabular}{clccccc}
\hline No & \multicolumn{1}{c}{ Unsur penilaian } & $\begin{array}{c}\text { Nilai } \\
\text { Maksimal }\end{array}$ & $\begin{array}{c}\text { Nilai } \\
\text { Minimal }\end{array}$ & Bobot & Skor & Jumlah \\
\hline 1 & Kelas tekstur tanah & 3 & 1 & 1 & 3 & 3 \\
2 & Ketebalan solum tanah & 3 & 1 & 1 & 2 & 2 \\
3 & Tingkat pelapukan batuan & 3 & 1 & 1 & 3 & 3 \\
4 & Kemiringan lereng & 15 & 5 & 5 & 3 & 15 \\
5 & Jenis morfologi & 9 & 3 & 3 & 3 & 9 \\
6 & Sejarah longsor & 3 & 1 & 1 & 2 & 2 \\
7 & Kerapatan vegetatif & 3 & 1 & 1 & 3 & 3 \\
8 & Penggunaan lahan & 3 & 1 & 1 & 2 & 2 \\
9 & Data curah hujan & 3 & 1 & 1 & 2 & 2 \\
\hline & $\quad$ Total & 45 & 15 & 15 & & $\mathbf{4 1}$ \\
\hline
\end{tabular}

Tabel 2. Pembobotan dan Penilaian Parameter Kerentanan

\begin{tabular}{llccccc}
\hline No & \multicolumn{1}{c}{ Unsur penilaian } & $\begin{array}{c}\text { Nilai } \\
\text { Maksimal }\end{array}$ & $\begin{array}{c}\text { Nilai } \\
\text { Minimal }\end{array}$ & Bobot & Skor & Jumlah \\
\hline 1 & $\begin{array}{l}\text { Jumlah Kepala Keluarga } \\
\text { dalam satu rumah }\end{array}$ & 3 & 1 & 1 & 2 & 2 \\
2 & $\begin{array}{l}\text { Jumlah anggota keluarga } \\
\text { dalam satu rumah }\end{array}$ & 3 & 1 & 1 & 3 & 3 \\
3 & Status kepemilikan rumah & 2 & 1 & 1 & 3 & 3 \\
4 & Status kepemilikan lahan & 2 & 1 & 1 & 2 & 2 \\
5 & Luas lahan & 3 & 1 & 1 & 1 & 1 \\
6 & Jenis bangunan & 9 & 3 & 3 & 2 & 6 \\
7 & Penggunaan lahan lainnya & 3 & 1 & 1 & 3 & 3 \\
\hline & $\quad$ Total & 25 & 9 & 9 & & $\mathbf{2 0}$ \\
\hline
\end{tabular}


Tabel 3. Pembobotan dan Penilaian Parameter Kapasitas

\begin{tabular}{|c|c|c|c|c|c|c|}
\hline No & Unsur penilaian & $\begin{array}{c}\text { Nilai } \\
\text { Maksimal }\end{array}$ & $\begin{array}{c}\text { Nilai } \\
\text { Minimal }\end{array}$ & Bobot & Skor & Jumlah \\
\hline 1 & $\begin{array}{l}\text { Jumlah Rumah Sakit, } \\
\text { Puskesmas, Polindes }\end{array}$ & 3 & 1 & 1 & 2 & 2 \\
\hline 2 & Jumlah Sekolah & 3 & 1 & 1 & 2 & 2 \\
\hline 3 & Jumlah Tenaga Medis & 3 & 1 & 1 & 2 & 2 \\
\hline 4 & Kelembagaan PRB & 3 & 1 & 1 & 3 & 3 \\
\hline 5 & Marka/tanda Jalur Evakuasi & 3 & 1 & 1 & 3 & 3 \\
\hline 6 & Sistem Peringatan Dini & 3 & 1 & 1 & 2 & 2 \\
\hline & Total & 18 & 6 & 6 & & 14 \\
\hline
\end{tabular}

2. Perhitungan Interval Zona Ancaman, Zona Kerentanan dan Zona Kapasitas

Perhitungan interval tiap parameter bencana didasarkan pada skor maksimum dan minimum dibagi dengan jumlah tingkatan zona risiko yang hendak disajikan pada peta risiko bencana. Interval tiap paramater dihitung sebagai berikut:

Interval zona ancaman $=\frac{\text { skor maks }- \text { skor } \min }{3}=\frac{45-15}{3}=10$

Interval zona kerentanan $=\frac{\text { skor maks }- \text { skor } \min }{3}=\frac{25-9}{3}=5,33005$

Interval zona kapasitas $=\frac{\text { skor maks }- \text { skor } \min }{3}=\frac{18-6}{3}=4$

Hasil pengklasifikasian zona berdasarkan hitungan interval penilaian masing-masing parameter tersebut disajikan pada Tabel 4.

Tabel 4. Klasifikasi Zona Ancaman, Kerentanan, dan Kapasitas

\begin{tabular}{ccc|ccc|ccc}
\hline \multicolumn{3}{c|}{ Zona ancaman } & \multicolumn{3}{c|}{ Zona kerentanan } & \multicolumn{3}{c}{ Zona kapasitas } \\
\hline $\begin{array}{c}\text { Interval } \\
\text { Skor }\end{array}$ & Kriteria & Zona & $\begin{array}{c}\text { Interval } \\
\text { Skor }\end{array}$ & Kriteria & Zona & $\begin{array}{c}\text { Interval } \\
\text { Skor }\end{array}$ & Kriteria & Zona \\
\hline $15-24$ & Rendah & Hijau & $9-14$ & Rendah & Hijau & $6-10$ & Rendah & Merah \\
$25-34$ & Sedang & Kuning & $15-19$ & Sedang & Kuning & $11-14$ & Sedang & Kuning \\
$35-45$ & Tinggi & Merah & $20-25$ & Tinggi & Merah & $15-18$ & Tinggi & Hijau \\
\hline
\end{tabular}

Hasil penilaian terhadap parameter ancaman pada Tabel 1 menunjukkan jumlah nilai ancaman longsor sebesar 41. Berdasarkan interval pada Tabel 5, nilai ancaman 41 termasuk dalam kriteria tinggi, hal ini berarti desa Girirejo mempunyai kriteria ancaman yang tinggi sehingga termasuk dalam zona merah. Pada penilaian parameter kerentanan, diperoleh jumlah skor sebesar 20 sehingga termasuk dalam zona merah, yaitu kriteria kerentanan tinggi, sedangkan untuk parameter kapasitas, diperoleh jumlah skor sebesar 14, sehingga desa Girirejo mempunyai kriteria kapasitas sedang dengan zona daerah kuning.

\section{Analisis Risiko Bencana}

Analisis risiko bencana tanah longsor merupakan gabungan dari 3 komponen utama yaitu ancaman $(\mathrm{H})$, Kerentanan (V) dan kapasitas (C). Masing-masing total 
bobot dari ancaman, kerentanan dan kapasitas untuk risiko ini akan memiliki nilai yang berbeda. Dari pembobotan nilai maksimal dan minimal dari masing masing ancaman, kerentanan dan kapasitas dijumlahkan kemudian diambil persentase dari masingmasing pembobotan tersebut terhadap jumlah total pembobotan. Dari persentase yang didapat kemudian dikalikan dengan masing-masing nilai maksimal dan minimal kriteria yang ditentukan. Hasil penilaian risiko bencana longsor disajikan pada Tabel 5. Sedangkan pengklasifikasian zona berdasarkan hitungan interval penilaian risiko bencana tersebut disajikan pada Tabel 6 .

Tabel 5. Pembobotan dan Penilaian Risiko Bencana

\begin{tabular}{llccccc}
\hline No & Unsur penilaian & $\begin{array}{c}\text { Nilai } \\
\text { Maks }\end{array}$ & $\begin{array}{c}\text { Nilai } \\
\text { Min }\end{array}$ & $\begin{array}{c}\text { Persentase/ } \\
\text { faktor Pengali }\end{array}$ & $\begin{array}{c}\text { Nilai Maks } \\
\text { Akhir }\end{array}$ & $\begin{array}{c}\text { Nilai Min } \\
\text { Akhir }\end{array}$ \\
\hline 1. & Ancaman & 45 & 15 & 0.5 & 22.5 & 7.5 \\
2. & Kerentanan & 25 & 9 & 0.3 & 7.5 & 2.7 \\
3. Kapasitas & 18 & 6 & 0.2 & 3.6 & 1.2 \\
\hline & Jumlah & 88 & 30 & 6 & 33.6 & 11.4 \\
\hline
\end{tabular}

Interval zona risiko $=\frac{\text { skor maks }- \text { skor min }}{3}=\frac{33,6-11,4}{3}=7,4$

Tabel 6. Klasifikasi Zona Risiko Bencana

\begin{tabular}{ccc}
\hline \multicolumn{3}{c}{ Zona risiko bencana } \\
\hline Interval Skor & Kriteria & Zona \\
\hline $11.4-18.8$ & Rendah & Hijau \\
$18.9-26.2$ & Sedang & Kuning \\
$26.3-33.6$ & Tinggi & Merah \\
\hline
\end{tabular}

\section{Pemetaan Risiko Bencana}

Pemetaan risiko bencana dilakukan dengan membagi area ke dalam tiga tingkatan zona risiko bencana, yaitu zona risiko rendah, sedang, dan tinggi yang pada peta ditampilkan dengan warna hijau, kuning, dan merah. Pembuatan peta risiko bencana tanah longsor pada penelitian ini menggunakan software ArcGis, versi 9.3. Software ini digunakan untuk menghitung persentase kemiringan lereng, dan menghitung serta mengevaluasi unit, klas atau tipe mana dari setiap individu peta yang penting (berpengaruh) terhadap kejadian gerakan tanah. Di samping itu juga dilakukan metode pendekatan kuantitatif (metode statistik) yang didasarkan pada perhitungan kerapatan (density) gerakan tanah dan nilai bobot (weight value) dari masing-masing unit, kelas atau tipe pada setiap peta parameter. Hasil peta risiko bencana longsor desa Girirejo, Bantul disajikan pada Gambar 2.

Berdasarkan Gambar 2, sebagian besar wilayah di desa Girirejo bagian timur dan utara memiliki tingkat risiko bencana tanah longsor sedang hingga tinggi (zona kuning hingga merah), sedangkan wilayah barat dan selatan cenderung mempunyai tingkat risiko bencana tanah longsor rendah. Dari lima pedukuhan di desa Girirejo, ada dua dukuh yang wilayahnya termasuk dalam zona hijau, yaitu dukuh Dronco/Gejayan dan Kranoman/Kradenan. Sedangkan dukuh Tegalrejo, Banyusumurup, dan Payaman Utara/Pajimatan sebagian besar wilayahnya berada pada zona kuning hingga merah, yang artinya sebagian besar berada pada zona risiko sedang hingga tinggi. 


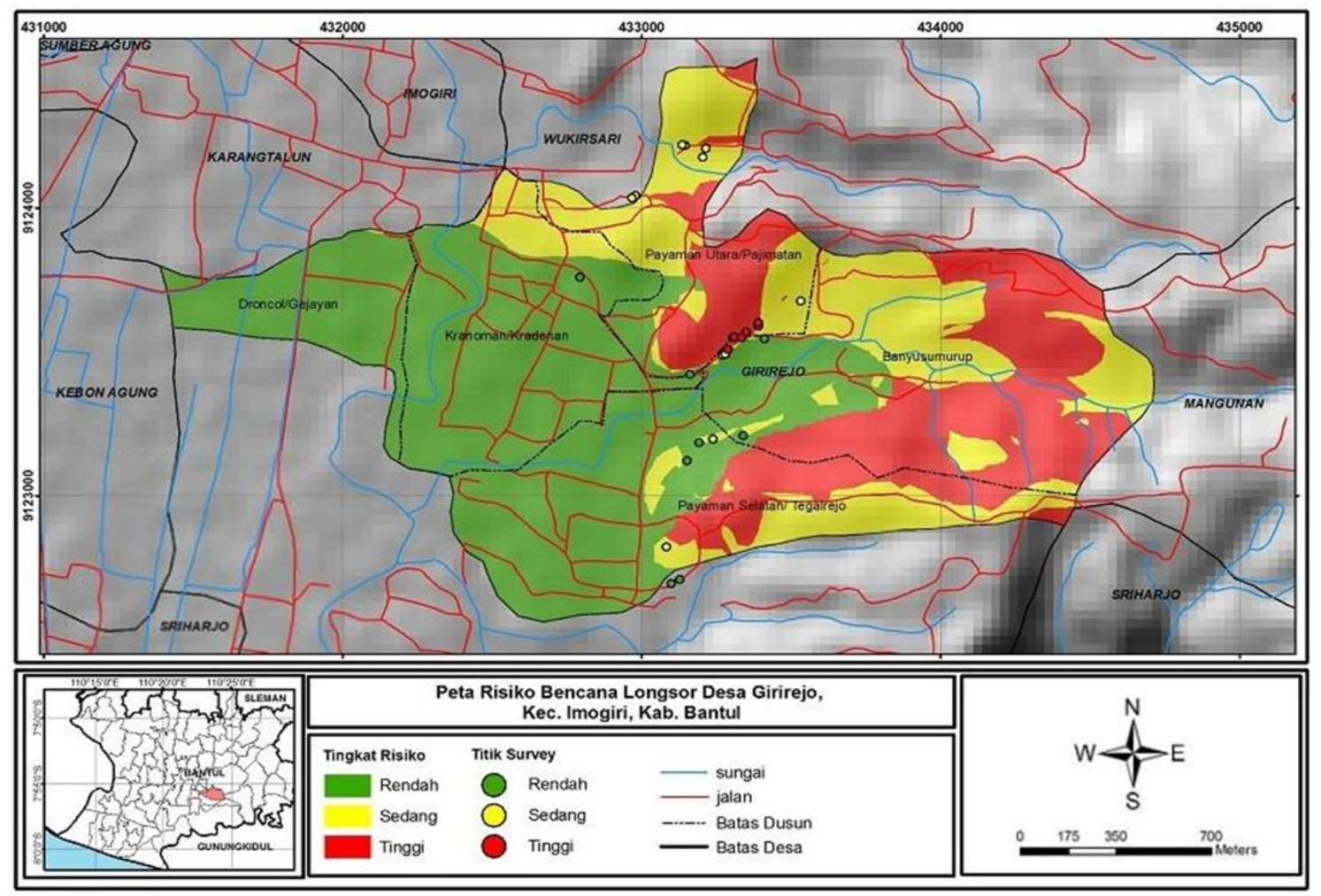

Gambar 2. Peta Risiko Longsor Desa Girirejo, Imogiri, Bantul

\section{Kajian Penataan Pemukiman}

Penataan pemukiman didasarkan pada hasil kajian analisis risiko bencana. Hasil penelusuran jumlah rumah (KK) yang berada pada dukuh yang mempunyai risiko bencana tanah longsor sedang hingga tinggi disajikan pada Tabel 7.

Tabel 7. Jumlah Rumah (KK) pada masing-masing Zona Bencana Tanah Longsor

\begin{tabular}{|c|c|c|c|c|c|}
\hline \multirow{2}{*}{\multicolumn{2}{|c|}{ Zona }} & \multicolumn{4}{|c|}{ Data Jumlah Rumah (KK) per dusun } \\
\hline & & Tegalrejo & Banyusumurup & Pajimatan & Total \\
\hline \multirow{3}{*}{$\begin{array}{c}\text { Zona } \\
\text { Ancaman }\end{array}$} & Zona Merah & 11 & 18 & 8 & 37 \\
\hline & Zona Kuning & 0 & 0 & 7 & 7 \\
\hline & Zona Hijau & 12 & 0 & 0 & 12 \\
\hline \multirow{3}{*}{$\begin{array}{c}\text { Zona } \\
\text { Kerentanan }\end{array}$} & Zona Merah & 3 & 4 & 1 & 8 \\
\hline & Zona Kuning & 2 & 5 & 0 & 7 \\
\hline & Zona Hijau & 0 & 0 & 0 & 0 \\
\hline \multirow{3}{*}{$\begin{array}{c}\text { Zona } \\
\text { Kapasitas }\end{array}$} & Zona Merah & 0 & 0 & 0 & 0 \\
\hline & Zona Kuning & 1 & 3 & 0 & 4 \\
\hline & Zona Hijau & 2 & 7 & 0 & 9 \\
\hline \multirow{3}{*}{$\begin{array}{l}\text { Zona } \\
\text { Risiko }\end{array}$} & Zona Merah & 3 & 18 & 0 & 21 \\
\hline & Zona Kuning & 8 & 0 & 15 & 23 \\
\hline & Zona Hijau & 12 & 0 & 0 & 12 \\
\hline
\end{tabular}

Tabel 7 menunjukkan bahwa jumlah rumah yang berada di zona merah adalah 21 rumah $(\mathrm{KK})$ dan zona kuning sebanyak 23 rumah (KK). Dalam upaya mitigasi 
bencana longsor, diperlukan penataan pemukiman khususnya di zona risiko sedang dan tinggi pebagai berikut:

1). Zona risiko tinggi

Wilayah tersebut harus dikosongkan dari pemukiman dan warga dipindahkan/direlokasi ke tempat yang aman dari semua bencana berdasarkan hasil kajian yang telah dilakukan dan dapat meningkatkan taraf hidup/perekonomian warga.

2). Zona risiko sedang

Wilayah ini masih dapat digunakan untuk pemukiman dengan beberapa persyaratan yaitu dengan diadakan/dibangun infrastruktur/non infrastruktur yang berbasis mitigasi bencana, antara lain :
a) Dinding penahan tanah
b) Saluran drainasi
c) Jalan Evakuasi
d) Penanaman pohon
e) Pelatihan kebencanaan
f) Simulasi kebencanaan

\section{SIMPULAN}

Hasil kajian analisis risiko bencana tanah longsor di Desa Girirejo, Imogiri, Bantul, menunjukkan bahwa zona kuning hingga merah yang mengindikasikan tingkat risiko sedang hingga tinggi berada di desa Girirejo bagian timur dan utara, sedangkan bagian barat dan selatan sebagian besar merupakan zona hijau (tingkat risiko bencana tanah longsor rendah). Hal ini sesuai dengan kondisi di lapangan, selain tingkat gerekan tanah yang menengah-tinggi, kondisi topografi wilayah barat dan selatan desa Girirejo cenderung datar, sedangkan bagian timur dan utara merupakan daerah perbukitan dengan kemiringan lereng yang curam, sehingga lebih berisiko terjadi longsor.

Dari ketiga zona risiko bencana tanah longsor, jumlah rumah yang berada di zona merah adalah 21 rumah (KK) dan zona kuning sebanyak 23 rumah (KK). Berdasarkan hasil kajian, untuk wilayah berisiko tinggi, hendaknya wilayah tersebut dikosongkan dari pemukiman dan warga dipindahkan/direlokasi ke tempat yang aman dari bencana, sedangkan untuk wilayah berisiko sedang, wilayah tersebut masih dapat digunakan untuk pemukiman dengan memenuhi beberapa syarat berbasis mitigasi bencana tanah longsor.

\section{DAFTAR PUSTAKA}

Aminatun, S. dan Muntafi, Y. (2018). Analisis Risiko Bencana Tanah Longsor sebagai Dasar dalam Mitigasi Bencana di Desa Selopamioro, Daerah Istimewa Yogyakarta, Indonesia. Prosiding Pekan IImiah Tahunan ke-5 Riset Kebencanaan Ikatan Ahli Kebencanaan Indonesia (IABI) Universitas Andalas, Padang 2-4 Mei 2018, 565-578.

Aminatun, S. dan Muntafi, Y. (2016). Kajian Analisis Risiko Bencana Tanah Longsor di Desa Terong Kecamatan Dlingo Kabupaten Bantul. Jurnal Teknisia, XXI (2), 250260.

Badan Nasional Penanggulangan Bencana (BNPB). (2015). Kerangka Kerja Sendai untuk Pengurangan Risiko Bencana 2015-2030. Jakarta: BNPB.

Badan Standardisasi Nasional 2005. Penyusunan Peta Zona Kerentanan Gerakan Tanah, SNI 13-7124-2005. Jakarta: BSN. 
Badan Nasional Penanggulangan Bencana (BNPB). (2012). Peraturan Kepala Badan Nasional Penanggulangan Bencana Republik Indonesia Nomor 02 tahun 2012 tentang Pedoman Umum Pengkajian Risiko Bencana. Jakarta: BNPB.

Badan Pertanahan Kabupaten Bantul. (2019). Data Kemiringan Lahan Wilayah di Kabupaten Bantul. Pemerintah Kabupaten Bantul. Diakses dari https://bantulkab.go.id/kemiringan-lahan

BAPPENAS-BAPEDA DIY-UNDP. (2008). Metode Pemetaan Risiko Bencana Provinsi Daerah Istimewa Yogyakarta. Yogyakarta: Badan Perencanaan Daerah Provinsi Daerah Istimewa Yogyakarta.

Faizana, F., Nugraha, A.L., dan Yuwono, B.D. (2015). Pemetaan Risiko Bencana Tanah Longsor Kota Semarang. Jurnal Geodesi Undip. 4 (1), 223-234.

Khafid, M.A. (2019). Analisis Penentuan Zonasi Pemukiman Risiko Bencana Tanah Longsor Berbasis Sistem Informasi Geografis: Studi Kasus Kecamatan Gedangsari, Kabupaten Gunung Kidul, Daerah Istimewa Yogyakarta. Jurnal Meteorologi Klimatologi dan Geofisika. 6 (1), 49-57.

Kementrian Energi dan Sumber Daya Mineral. (2019, Desember 19). Peta Prakiraan Wilayah Terjadinya Gerakan Tanah pada Bulan Desember 2019, Kabupaten Bantul dan Kota Yogyakarta. Diakses dari https://vsi.esdm.go.id/

Nugraha, A.L. (2013). Penyusunan dan Penyajian Peta Online Risiko Bencana Banjir Rob Kota Semarang. Yogyakarta: Teknik Geomatika Universitas Gajah Mada.

Permadi, M.G., Tjahjono, B., dan Baskoro, D.P.T. (2018). Identifikasi Daerah Risiko Bencana Longsor di Kota Bogor. Jurnal IImu Tanah dan Lingkungan. 20 (2), 8694.

Undang-Undang Republik Indonesia Nomor 24 tahun 2007 tentang Penanggulangan Bencana.

United Nations-International Strategy on Disaster Reduction (UNISDR). (2007). Global Platform for Disaster Risk Reduction. Switzerland: UNISDR. 